\title{
HISTORY OF GEOPHYSICAL STUDIES AT THE WASTE ISOLATION PLO'T PLANT (WIPP), SOUTHEASTERN NEW MEXICO*
}

\author{
David J. Borns \\ Geophysics Department \\ Org. 6116/MS-0750 \\ Sandia National Laboratories \\ Albuquerque. NM 87185-0750
}

\begin{abstract}
A variety of geophysical methods including the spectrum of seismic, electrical, electromagnetic and potential field techniques have supported characterization, monitoring and experimental studies at the Waste Isolation Pilot Plant (WIPP). The geophysical studies have provided significant understanding of the nature of site deformation. tectonics and stability. Geophysical methods have delineated possible brine reservoirs beneath the underground facility and have defined the disturbed rock zone that forms around underground excavations. The role of geophysics in the WIPP project has evolved with the project. The early uses were for site characterization to satisfy site selection criteria or factors. As the regulatory framework for WIPP grew since 1980, the geophysics program supported experimental and field programs such as Salado hydrogeology and underground room systems and excavations. In summary, the major types of issues that geophysical studies addressed for WIPP are:
\end{abstract}

\section{- Issue 1: Site Characterization}

- Issue 2: Castile Brine Reservoirs

- Issue 3: Rustler /Dewey Lake Hydrogeology

- Issue 4: Salado Hydrogeology

- Issue 5: Excavation Effects

The nature of geophysics programs for WIPP has been to support investigation rather than being the principal investigation itself. The geophysics program has been used to define conceptual models (e.g., the Disturbed Rock Zone-DRZ) or to test conceptual models (e.g., high transmissivity zones in the Rustler Formation). The geophysics program primarily supported larger characterization and experimental programs. Funding was not available for the complete documentation and interpretation. Therefore, a great deal of the geophysics survey information resides in contractor reports.

* This work was supported by the United States Department of Energy under comract DE-AC04-94AL85000

Sandia is a multiprogram laboratory operated by Sandia Corporation, a Lockheed Martin Company for the United Sates Department of Energy

\section{INTRODUCTION}

A variety of geophysical methods including the spectrum of seismic, electrical, electromagnetic and potential field techniques have been used support characterization, monitoring and experimental studies at the Waste Isolation Pilot Plant (Figure 1). This document will provide a historical overview and context of the WIPP geophysical studies since 1975 when Sandia National Laboratories assumed the site characterization activities in the northern Delaware Basin. Oak Ridge National Laboratory (ORNL) conducted the preliminary characterization studies in the Delaware Basin prior to 1975 including the drilling of exploratory holes AEC-7 and AEC-8.

Several other publications give an important overview of the geophysical studies at WIPP. These include an annotated bibliography (Powers and Martin, 1993), which identifies and summarizes the geophysical reports 
available in the WIPP Central File'; the geological characterization report (Powers and others, 1978), which describes the early characterization studies, in particular the surface seismic reflection studies; and the site deformation report (Borns and others, 1983), which includes interpretations of seismic and gravity data at the WIPP site.

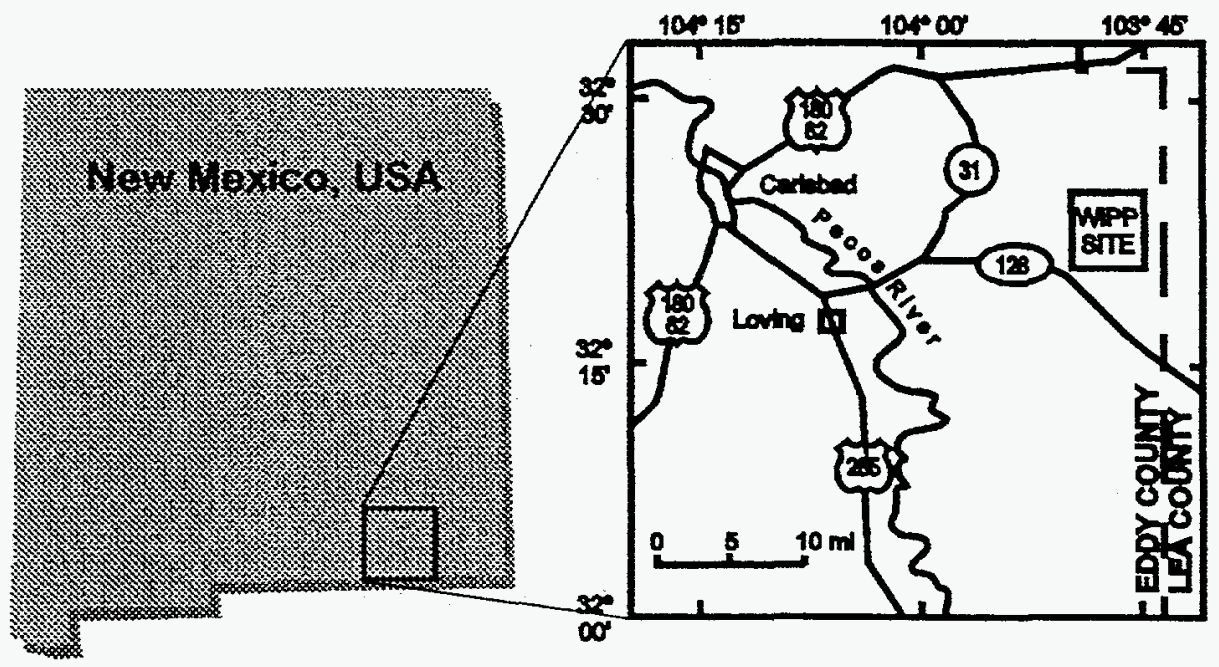

Figure 1: Location of the WIPP site . southeastern New Mexico

\section{APPROACH OF THIS REPORT}

The approach of this report is to view the various geophysical studies in the context of evolving project issues and their resolution. Therefore, this report will not be an exact time line of geophysical studies. The major types of issues that geophysical studies addressed are (Figure 2):

- Issue 1: Site Characterization

- Issue 2: Castile Brine Reservoirs

- Issue 3: Rustler /Dewey Lake Hydrogeology

- Issue 4: Salado Hydrogeology

- Issue 5: Excavation Effects

As the WIPP Project and its regulatory framework evolved, the scope and relative importance of these issues changed. For example, the seismic reflection surveys of 1970 s had the objective of defining the lateral continuity of the rocks underlying the site and the absence of structural features that would hinder site construction. These surveys were not designed to answer issues of the 1990's such as mapping facies variations in the Culebra Dolomite Member of the Rustler Formation. The use of geophysical methods within the WIPP project evolved through the geological characterization stage, the Final Environmental Impact Statement (FEIS), the site and preliminary design validation (SPDV) report, the DOE/State of New Mexico Agreement for Consultation and Concurrence, and support of modeling approaches for Performance Assessment calculations and licensing. Reviews of the project criteria and issues of the 1970's are in the FEIS and of early 1980's are in Weart's (1983) summary reports on Site Preliminary Design Validation (SPDV).

'WIPP Central File is part of the Sandia National Laboratories Nuclear Waste Managment Center (6800) library, telephone number 505/848-0810 


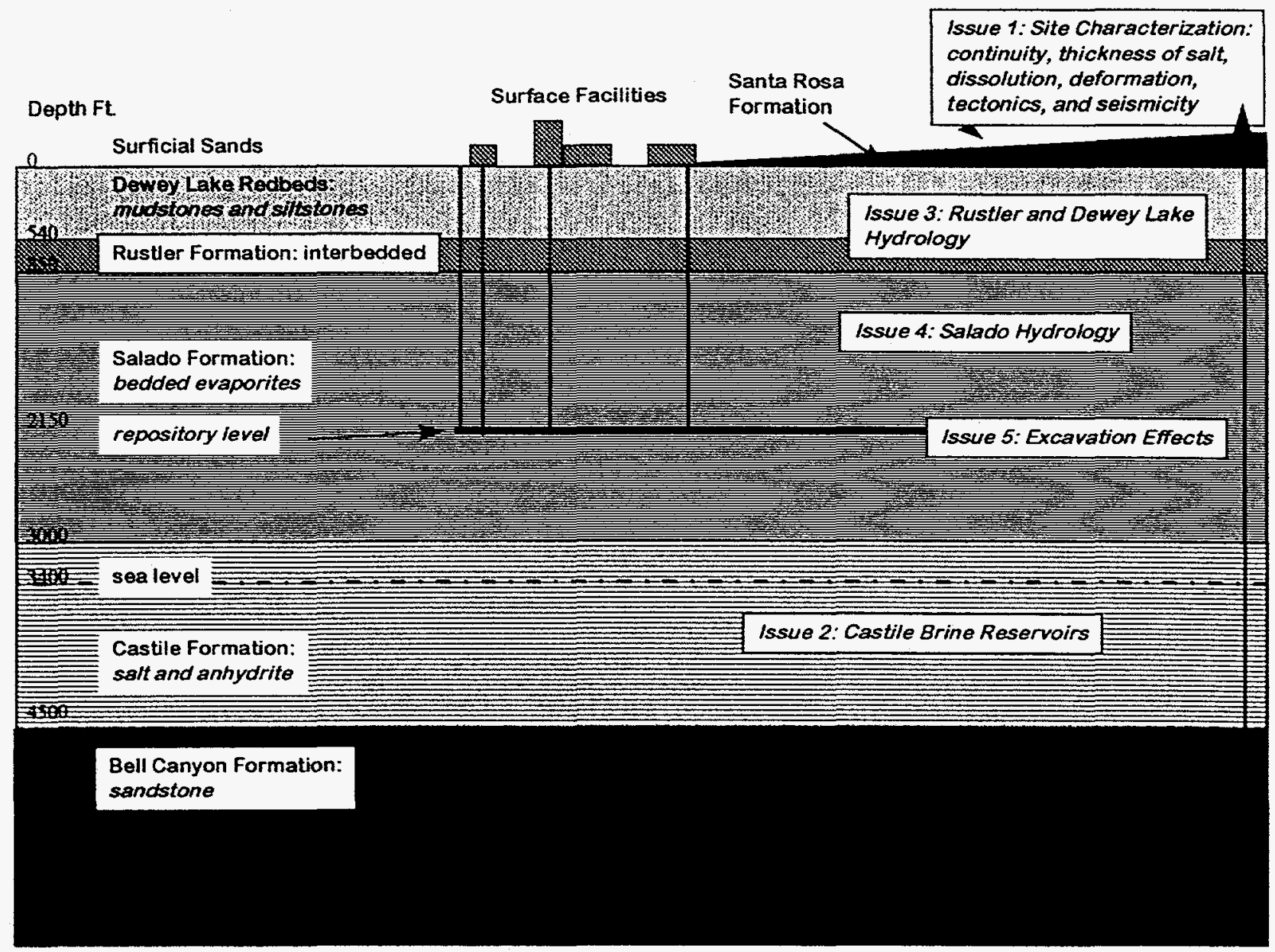

Figure 2: WIPP site geology and stratigraphy relative to facilities and issues addressed by geophysics

\section{WIPP ISSUES}

\section{Issue 1: Site Characterization}

In 1972, the Atomic Energy Commission (AEC) rejected the proposed Lyons, Kansas, salt-hosted repository site due to improperly plugged oil and gas wells and nearby solution mining with loss of fluids. By the early 1970's, ORNL selected the Delaware Basin as a possible alternate location for the demonstration repository. The early site characterization studies and the geophysical studies for the Delaware Basin site were influenced by the experience of AEC at the Lyons, Kansas site. Principal site selection criteria for the Delaware Basin site, in part based on experience in Kansas; were avoidance of drill holes, avoidance of the dissolution front of Nash Draw, and avoidance of the Capitan Reef. The major effort was to find a site that was at least one mile from any existing borehole. This distance was based on the analysis of Snow and Chang in the FEIS (USDOE, 1980), which indicated that dissolution by water flowing through an inadequately plugged borehole through the Salado Formation would not progress a mile from its source in 250,000 years. Of the site selection criteria and factors during the early characterization stage, geophysical studies were used to address the following (see for example, Weart. 1983):

- Continuity and predictability of strata

- Thickness of salt

- Extent of dissolution 
- Deformation: faults, halokinesis, breccia pipes, uplift and subsidence, igneous activity

- Tectonics: seismicity

- Early site selection criteria and factors

References: Griswold, 1977; USDOE, 1980; Powers and others, 1978; Weart, 1983; Bechtel National, 1986

Resolution: Characterization studies determined that layering showed continuity and maintained the required thickness. The site was basically stable: the seismic risk was determined and no known Quaternary tectonic faulting near proposed site was observed. Surface studies and electrical profiling indicate an absence of breccia pipes or similar scale dissolution features in the Los Medaños site area (a portion of the previously defined Delaware Basin site).

- Continuity and predictability of strata

References: Borns and others, 1983; Powers and others, 1978; Dobrin, 1979; Hern and others, 1979; G. J. Long and Associates, 1976; Barrow's and Fett, 1985

Resolution: Chaotic reflectors detected in Castile Formation near site. These were determined to be halokinetic effects on Castile and Salado structures. Characterization studies confirmed gentle basin tilt and continuity of bed thickness.

- Thickness of Salt

References: Borns and others, 1983; Powers and others, 1978; Bell and Murphv, 1979; Dobrin, 1979; Hern and others, 1979; G. Long and Associates, 1976

Resolution: Characterization studies confirmed gentle basin tilt and continuity of bed thickness.

- Extent of Dissolution

References: Elliot Geophysical (1976a, 1976b, 1977); Bartel, 1989; James and Borns (1993)

Resolution: Surface studies were ambiguous on shallow dissolution; continuity or relation to halokinesis provides evidence against deep dissolution.

- Deformation: faults, halokinesis, breccia pipes, upliff and subsidence, igneous activity

References: Borns and others, 1983; Powers and others, 1978; Dobrin, 1979; Hern and Associates, 1979; G. Long and Associates, 1976; Elliot Geophysical (1976a, 1976b, 1977); Barrows and Fett, 1983; Barrow's and Fett, 1985; Wieduwilt, 1977

Resolution: Surface studies and electrical profiling indicate an absence of breccia pipes or similar scale dissolution features in the Los Medanos site area. Geophysical studies were consistent with the conclusion that faults, halokinesis, uplift and subsidence, igneous activity in the immediate area of the proposed site did not significantly affect long term performance.

- Tectonics: seismicity

References: Powers and others, 1978; USDOE, 1980, Sanford and others, 1980

Resolution: The regional seismicity is related to two main clusters associated with the Rio Grande Rift to the southwest of the site and the Central Basin Platform to the east of the site. The upper magnitude limit for the WIPP site was set 4.5 to 5 . The possible acceleration at the site was set at $0.3 \mathrm{~g}$. The possibility of an event at the site of a magnitude that could significantly affect the repository was determined to be very low.

\section{Issue 2: Castile Brine Reservoirs}

A number of hydrocarbon-exploration borcholes and two WIPP characterization boreholes (ERDA-6 in 1975 and WIPP-12 in 1981) have encountered pressurized brine in the Castile Formation (Powers and others, 1978; Lappin and Hunter, 1989). These reservoirs are thought to be associated with a fracture porosity in the anhydrite members 
of the Castile Formation. These fractures are interpreted to be associated with the halokinetic deformation of the Castile in the northern Delaware Basin adjacent to the reef margin. During the early and middle stages of site characterization, the geophysical program largely concentrated on the development and validation of methods to delineate brine reservoirs beneath the WIPP site.

- Delineation of reservoirs beneath the WIPP site and Development/validation of methods for use at WIPP

References: Elliot, 1982; Bartel and others, 1983; Earth Technologv Corporation, 1988

Resolution: A TDEM survey was conducted above the waste panel area. One dimensional inversion of the data indicated high electrically conductive regions within the Castile beneath the repository. These high conductivity regions are interpreted to represent brine reservoirs.

\section{Issue 3: Rustler and Dewey Lake Hydrogeology}

Beginning with the early site selection criteria, the WIPP project was concerned with siting the WIPP facility sufficiently distant from zones of active dissolution. The early criterion was a distance of one mile. Another factor was the presence or absence of faults crossing the Rustler and Dewey Lake formations. In 1975, Mississippi Chemical Corporation mined under a surficial collapse dome in northwestern end of Nash Draw. The excavation encountered a "breccia pipe." Concern grew regarding consequences of a breccia pipe forming under the repository. In the early 1980's, question of karst formation in the WIPP site area became an issue (Bachman, 1985. 1987).

The Rustler Formation contains the major water bearing units above the repository facility (Siegel and others. 1989: Lappin and Hunter, 1989, Beauheim, 1989; Beauheim and Holt, 1990). This unit has been the focus of hydrologic investigation at the site. The basic characterization issues are lateral variations in water bearing units, presence or absence of vertical connections such as faults. and variations in porosity and permeability.

- Dissolution features, Karst, Fractures, and Faults

References: Barrows and others, 1983; Barrows and Fett, 1985

Resolution: Variations in microgravity were interpreted to represent mass removal in the near surface. Such mass removal was interpreted to possibly represent dissolution. The resolution of the model came from core. stratigraphic, and geochemical studies (Holt and Powers, 1988; Lappin and Hunter, 1989; Beauheim, 1989; Beauheim and Hoit, 1990). The small observed changes in density are attributed primarily to lateral facies changes within the near surface stratigraphic units.

- Variations in porosity and permeability

References: Elliot Geophysical, 1976a, 1976b, 1977; Bartel, 1989; James and Borns, 1993

Resolution: The interpretation of the data identifies two conductive features in the section overlying the Salado Formation, both trending roughly north-south. The western anomaly lies in the lower half of the Dewey Lake Formation and may directly overlie part of the storage facility. The eastern anomaly lies within the Rustler Fonnation, probably the Culebra Dolomite Member, 1000 meters east of the repository. The Dewey Lake anomaly overlies the Rustler anomaly in part, thus suggesting a relationship between the two. There is also some suggestion that the strong conductive feature in the Rustler, at a distance of about 2500 meters to the east of the storage facility, may have vertical extension upward into the Dewey Lake.

\section{Issue 4: Salado Hydrogeology}

Since the early excavation of the underground facility in 1982, brine seeping from excavation surfaces and into boreholes has been observed. These observations raised questions regarding the presence of a brine or two-phase flow system within the host evaporites of the Salado Formation. This hydrologic system may affect waste degradation and the effectiveness of underground seals.

- Brine flow around excarations 
- Brine flow in fractures

- Variation in porosity and permeability

References: Borns and Stormont, 1988 a, b, 1989; Cook, 1982; Jung, 1991; Jung and others, 1991; Neuman, 1993; Pfeifer and others, 1989; Skokan and others, 1987; Starrett, 1989; Truskowski and Andersen, 1993; Unterberger, 1981

Resolution: We have established the relationship between brine inflow measured in Room Q to changes in electrical properties such that electrical properties can be used to estimate hydrologic properties and predict brine inflow at other localities in the time. Desaturation and the formation of new porosity occur in the Disturbed Rock Zone (DRZ) early after excavation. In a sealed room, the porosity resaturates with brine influx into the DRZ. The DRZ provides a significant reservoir for the initial brine inflow into an excavation. Electrical surveys have delineated brine-filled fractures and non-filled fractures in the excavation floor.

\section{Issue 5: Excavation Effects}

Following excavation of underground openings at WIPP, a DRZ forms in the wall rock (Figures 3 and 4). The extent of the DRZ around workings at WIPP is delineated by the zone of rock in which mechanical properties and hydrologic properties have changed in response to the excavation. The processes involved in the development of a DRZ are complex, although related to stress relief and/or rapid strain rates. The redistribution of stress around the excavation drives coupled processes such as changes in permeability in response to fracture growth. The development of the DRZ affects brine flow around the excavation and seal emplacement.

\section{- Extent of the $D R Z$}

- Changes in the mechanical and hydrologic properties of the DRZ with time

- Effects of the DRZ on seal design and location

References: Borns and Stormont (1988 a,b, 1989); Cook, 1982; Jung, 1991; Jung and others, 1991; Holcomb, 1988; Kannenberg and others, 1990; Pfeifer and others, 1989; Skokan and others, 1987; Starrett, 1989;

Truskowski and Andersen, 1993; Unterberger, 1981, Williams, 1991

Resolution: The development of microfractures and mesofractures affects both brine inflow and the dissipation of gasses around the WIPP excavation by creating new interconnected pore space. Both fracturing and fluid flow are difficult to observe in boreholes alone. But fracture formation results in changes in electrical resistivity and seismic velocity. Multiple methods map similar distribution of fracturing in the $\mathrm{DRZ}$ and provide verification of the individual methods.

\section{SUMMARY}

A variety of geophy'sical methods including the spectrum of seismic, electrical, electromagnetic and potential field techniques supported characterization, monitoring and experimental studies at the Waste Isolation Pilot Plant. The geophysical studies have provided significant understanding to nature of site deformation, tectonics and stability. Geophysical methods have delineated possible brine reservoirs beneath the underground facility and have defined the Disturbed Rock Zone(DRZ) that forms around underground excavations. 


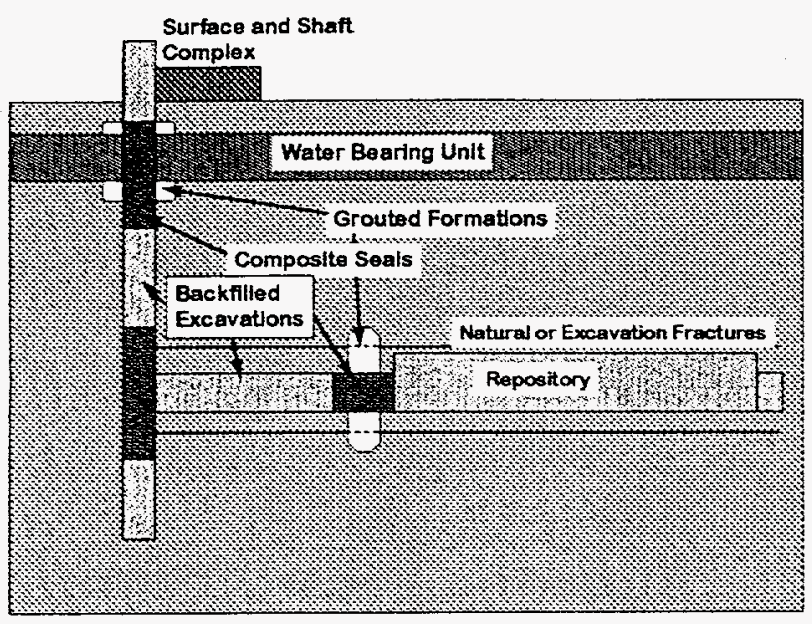

Figure 3: Components of a repository containment svstem

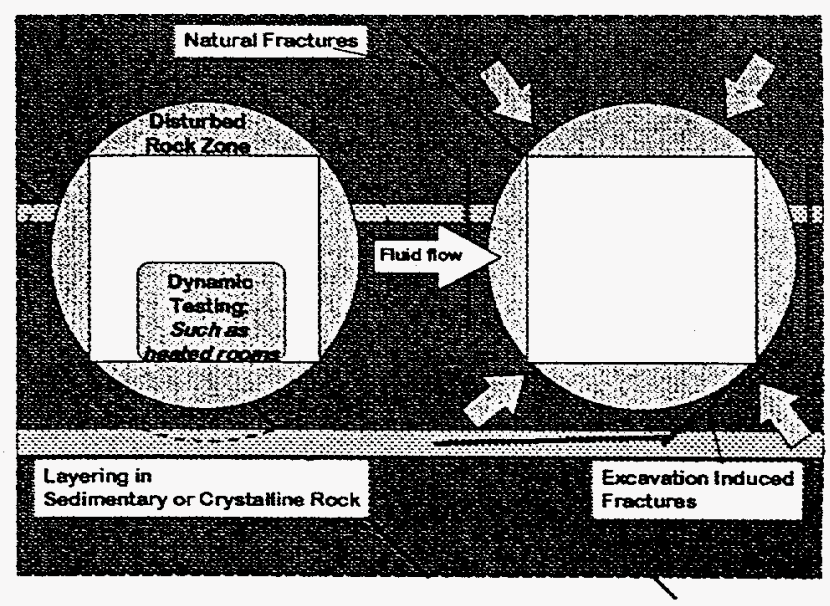

Figure 4: Features and Processes associated with underground repository excavations

The role of geophysics in the WIPP project has evolved with the project. The early uses were for site characterization to satisfy qualification criteria or factors. As the regulatory framework for WIPP grew since 1980. the geophysics program focused on support of experimental and field programs such as Salado hydrogeology and room systems. The nature of geophysics program has been to support investigation rather than being the principal investigation. The geophysics program has been used to define conceptual models (e.g., DRZ) or to test conceptual models (e.g., high transmissivity zones in the Rustler Formation). Since the geophysics program primarily supported larger characterization and experimental programs and not a stand alone program; funding was not available for the complete documentation and interpretation. Therefore, a great deal of the geophysics survey information resides in contractor reports.

Another important consideration is that the WIPP geophysics strove to utilize state-of-the-art geophysical methods for each of the issues. However, by 1997 some of geophysical studies were 20 to 25 years old. The question will remain unanswered on the effect of hypothetically using methods of the 1990's such as three dimensional seismic and electromagnetic imaging on the characterization studies of the 1970's. This author believes that if the project hypothetically started over with such 1990's methods the conclusions regarding the basic issues would remain the same but that the uncertainty would decrease.

\section{REFERENCES}

Bachman. G. O., 1985, Assessment of Near-Surface Dissolution at and near the Waste Isolation Pilot Plant (WIPP), southeastern New Mexico, SAND84-7178, Sandia National Laboratories, Albuquerque, NM

Bachman, G. O., 1987, Karst in Evaporites in southeastern New Mexico, SAND86-7078. Sandia National Laboratories, Albuquerque, NM

Barrows, L. G., S.-E. Shaffer, W. B. Miller, and J. D. Fett, 1983: Waste Isolation Pilot Plant (WIPP) Site Gravity Survey and Interpretation, SAND82-2922, Sandia National Laboratories, Albuquerque, NM

Barrows, L. G., and J. D. Fett, 1985: A high precision gravity survey in the Delaware Basin of southeastern New Mexico, Geophysics, 50, 825-833 
Bartel, L. C., 1989, Results from electromagnetic surface surveys to characterize the Culebra aquifer at the WIPP site, SAND87-1246, Sandia National Laboratories, Albuquerque, NM

Bartel. L.C., R. D. Jacobsen, and S.-E. Shaffer, 1983, Results from mapping the brine pocket encountered at WIPP 12 using the CSAMT Geophysical Technique, , SAND83-0458, Sandia National Laboratories, Albuquerque, NM

Beauheim. R. L., 1989, Interpretations of hydraulic-interference tests of the Culebra Dolomite conducted at $\mathrm{H}-2, \mathrm{H}$ 4, H-5, H-6, H-7, and H-9 hydropads at the Waste Isolation Pilot Plant (WIPP) site: SAND89-0869, Sandia National Laboratories, Albuquerque, NM.

Beauheim, R. L., and R. M. Holt, 1990, Hydrogeology of the WIPP site, in Powers, D.. R. Holt, R. L. Beauheim. and N. Rempe, 1990, Geological and Hydrological Studies of Evaporites in the northern Delaware Basin for the Waste Isolation Pilot Plant (WIPP), New Mexico, Geological Society of America Field Trip \#14 Guidebook, 1990 Annual Meeting, Dallas, TX. 131-179

Bechtel National, 1986, Waste Isolation Pilot Plant, Design Validation Final Report, prepared for the U.S. Department of Energy, Bechtel National. Inc., Advanced Technology Division, San Francisco, California

Bell \& Murphy and Associates, 1979, Geophysical investigation of the Waste Isolation Pilot Plant Eddy County. New Mexico, Bell \& Murphy and Associates, Dallas, TX

Borns, D. J., L.G. Barrows, D. W. Powers, and R. P. Snyder, 1983, Deformation of Evaporites near the Waste Isolation Pilot Plant (WIPP) Site, SAND82-1069, Sandia National Laboratories, Albuquerque, N

Borns, D. J., and J. S. Stormont, 1988a, "An interim report on excavation effect studies at the Waste Isolation Pilot Plant: the Delineation of the Disturbed Rock Zone," SAND87-1375. presented at and published by The Workshop on Excavation Effects, OCED/NEA

Borns, D. J., and J. C. Stormont, 1988b. An Interim Report on Excavation Effect Studies at the Waste Isolation Pilot Plant: The Delineation of the Disturbed Rock Zone, Sandia Report. SAND 87-1375. Sandia National Laboratories, Albuquerque, NM

Borns, D. J., and J. C. Stormont, 1989, The delineation of the disturbed rock zone surrounding excavations in salt. 353-368, In Khair, A. W, editor, Proc. 30th U.S. Symposium on Rock Mechanics, Morgantown, West Virginia, A. A. Balkema, Rotterdam, $972 \mathrm{p}$

Cook, C. W., 1982, Underground scanning with an Impulse Radar, SAND82-0470, Sandia National, Laboratories, Albuquerque, NM

Dobrin, M. B., 1979. Consultant's report on the seismic survey of WIPP site conducted by Bechtel in 1979, Document No. 22-V-510-03 Bechtel National, San Francisco, CA

Earth Technology Corporation, 1988, Final report for time domain electromagnetic (TDEM) Surveys at the WIPP Site, SAND87-7144, Sandia National Laboratories, Albuquerque, NM

Elliot, C. L., 1982, Evaluation of the suitability of electrical geophysical techniques for detection and/or mapping brine reservoirs in the Castile Formation, Elliot Geophysical Company, Tucson, AZ

Elliot Geophysical Company, 1976a, An experimental detailed gravity survey of known or suspected breccia pipes at Weaver Hills, Hill A\&B, and Hills C\&D, Eddy County, New Mexico, Elliot Geophysical Company, Tucson, AZ

Elliot Geophysical Company, 1976b, An experimental detailed resistivity survey of known or suspected breccia pipes, Eddy County, New Mexico, Elliot Geophysical Company, Tucson, AZ

Elliot Geophysical Company, 1977, Evaluation of the proposed Los Medanos nuclear waste disposal site by means of electrical resistivity surveys, Eddy \& Lea Counties, New Mexico, Elliot Geophysical Company, Tucson, $\mathrm{AZ}$ 
Griswold, G. B., 1977, Site selection and evaluation studies of the Waste Isolation Pilot Plant (WIPP). Los Medanos, Eddy County, NM, Sandia Report, SAND77-0946, Sandia National Laboratories, Albuquerque, NM

Hern, J. L., D. W. Powers, and L. G. Barrows, 1979, Seismic reflection data report Waste Isolation Pilot Plant (WIPP) Site, southeastern New Mexico, Sandia Report, SAND79-0264, V. 1-2, Sandia National Laboratories, Albuquerque, NM

Holcomb, D. J., 1988, Cross-Hole measurements of velocity and attenuation to detect a disturbed zone in salt at the Waste Isolation Pilot Plant, SAND87-3016C, Key Questions in Rock Mechanics: Proceedings of the 29thUS Symposium, University of Minnesota, Minneapolis, MN, June 13-15, 1988, P. A. Cundall, R. L. Sterling, and A. M. Starfield, editors, A. A. Balkema, 633-640

Holt, R. M., and D. W. Powers, 1988, Facies variability and post-depositional alteration within the Rustler Formation within the vicinity of the Waste Isolation Pilot Plant, southeastern New Mexico: DOE/WTPP 88-004, U.S. Department of Energy, Carlsbad, NM

James, B. A., and D. J. Borns, 1993, Two-dimensional subsurface imaging with transient EM for mapping a buried dissolution structure near the Waste Isolation Pilot Plant, Proceedings of the Symposium on the Application of Geophysics to Engineering and Environmental Problems. Environmental and Engineering Geophysics Society, 2, 633-656

Jung, Y., 1991, Mapping Fractures in Salt Using High-Resolution Seismic Tomography. Ph.D. Dissertation, T3862, Colorado School of Mines

Jung. Y., A. Ibrahim, and D. Borns, 1991, Mapping fracture zones in salt: High-resolution, cross-gallery seismic tomography, Geophysics: The Leading Edge of Exploration, 10, 37-39

Kannenberg. M., C. Francke, and W. M. Roggenthen, 1990, Ground probing studies of the Waste Isolation Pilot Plant (WIPP) Underground. Abstracts with Programs. Geological Society of America. 22, 99-100

Lappin, A. R., and R. L. Hunter, editors, 1989, Systems analysis, long term radionuclide transport, and dose assessment, Waste Isolation Pilot Plant (WIPP), southeastem New Mexico, Sandia Report, SAND890462, Sandia National Laboratories, Albuquerque, NM

Long, G. J., and Associates, Inc., 1976, Interpretation of geophysical data from Los Medanos and vicinity, Lea and Eddy Counties, New Mexico, G.J. Long and Associates, Inc. Houston, Texas

Neuman, D. I., 1993, Modified mise-a-la-masse measurement to map brine invasion beneath the floor of an underground excavation at the WIPP site, SE, New Mexico. Proceedings of the Symposium on the Application of Geophysics to Engineering and Environmental Problems, Environmental and Engineering Geophysics Society, 2, 659-667

Pfeifer, M. C., D. J. Borns, C. K. Skokan, H. T. Andersen, and J. M. Starrett, 1989, Geophysical methods to monitor development of the Disturbed Rock Zone around underground excavations in bedded salt, SAND89-7055, Sandia National Laboratories, Albuquerque, NM

Powers, D. W., S. J. Lamber, S.-E. Shaffer, L. RE. Hill, and W. D. Weart, editors, 1978, Geological characterization report, Waste Isolation Pilot Plant (WIPP) site, southeastern New Mexico, Sandia Report, SAND78-1596, vol. 1-2, Sandia National Laboratories, Albuquerque NM

Powers, D. W., and M. L. Martin, 1993, A select bibliography of reports related to Waste Isolation Pilot Plant geotechnical studies (1972-1990), Sandia Report, SAND92-7277, Sandia National Laboratories. Albuquerque, NM

Sanford, A. R., S. Sanford, T. C. Wallace, L. J. Barrows, J. Sheldon, R. M. Ward, S. Johansen, and L. Merritt, 1980, Seismicity in the area of the waste Isolation Pilot Plant (WIPP), SAND80 7096, Sandia National Laboratories, Albuquerque, NM 
Siegel, M. D., S. J. Lambert, and K. L. Robinson, editors, 1989, Hydrogeochemical facies of the Rustler Formation and related rocks in the WIPP area, southeastern New Mexico, Sandia Report, SAND88-0196, Sandia National Laboratories, Albuquerque, NM

Skokan, C. K., M. C. Pfeifer, G. V. Keller, and H. T. Andersen, 1987, Studies of electrical and electromagnetic methods for characterizing salt properties at the WIPP Site, New Mexico, Sandia Report, SAND87-7174. Sandia National Laboratories, Albuquerque, NM

Starrett, J. M., 1989, A feasibility study for using seismic tomography to monitor the integrity of salt pillars, M.S. thesis Colorado School of Mines. Golden CO

Truskowski. M., and H. T. Andersen, 1993, Resistivity changes over time related to modeled fluid flow in Room-Q of the Waste Isolation Pilot Plant. Proceedings of the Symposium on the Application of Geophysics to Engineering and Environmental Problems (SAGEEP), Environmental and Engineering Geophysical Society, 545-558

U.S. Department of Energy, 1980, Final Environmental Impact Statement, Waste Isolation Pilot Plant, DOE/EIS0026

Unterberger, R. B., 1981, Final report on subsurface radar applications in the Delaware Basin, covering the period June 1, 1980, through January 31, 1981, Texas A\&M, Department of Geophysics. College Station. TX

Weart. W. D., 1983, Summary evaluation of the Waste Isolation Pilot Plant (WIPP) site suitability, Sandia Report. SAND 83-0450. Sandia National Laboratories, Albuquerque, NM

Wieduwilt. W. G, 1977, Electrical geophysical surveys of the Los Medanos Site and surrounding areas for the Waste Isolation Pilot Plant program. Eddy and Lea counties. New Mexico, Mining Geophysical Surveys, Inc. Tucson. AZ

Williams, E. M., 1991, A boundary element direct current resistivity model to aid in the interpretation of an underground DC resistivity multicomponent survey, M.S. thesis, T-3892, Colorado School of Mines, Golden

incorporates review of

D. W. Powers, $12 / 20 / 96$

M. C. Walck, 1/13/97, 2/18/97

W. D. Weart, 1/20/97

S. Lambert $1 / 20 / 97$

G. Elbring, 1/7/97

\section{DISCLAIMER}

This report was prepared as an account of work sponsored by an agency of the United States Government. Neither the United States Government nor any agency thereof, nor any of their employees, makes any warranty, express or implied, or assumes any legal liability or responsibility for the accuracy, completeness, or usefulness of any information, apparatus, product, or process disclosed, or represents that its use would not infringe privately owned rights. Reference herein to any specific commercial product, process, or service by trade name, trademark, manufacturer, or otherwise does not necessarily constitute or imply its endorsement, recommendation, or favoring by the United States Government or any agency thereof. The views and opinions of authors expressed herein do not necessarily state or reflect those of the United States Government or any agency thereof. 


\section{DISCLAIMIER}

Portions of this docoment may be illegible in electronic image products. Images are produced from the best available original docoment. 